\title{
PENGGUNAAN GAYA BAHASA PERSONIFIKASI DALAM KUMPULAN PUISI KARYA MAHASISWA FKIP BAHASA DAN SASTRA INDONESIA UNIVERSITAS BALIKPAPAN
}

\author{
Maryatin \\ Program Studi Pendidikan Bahasa dan Sastra Indonesia, Universitas Balikpapan \\ maryatin@uniba-bpn.ac.id
}

\begin{abstract}
ABSTRAK
Penelitian ini bertujuan untuk mendeskripsikan gaya bahasa dalam Kumpulan Puisi Karya Mahasiswa FKIP Bahasa dan Sastra Indonesia Universitas Balikpapan. Kumpulan puisi Karya Mahasiswa FKIP Bahasa dan Sastra Indonesia ditulis oleh 26 mahasiswa sebanyak 52 puisi. Sumber data primer dalam penelitian ini adalah kumpulan puisi karya Mahasiswa FKIP Bahasa dan Sastra Indonesia sejumlah 60 halaman. Sumber data sekunder dalam penelitian ini adalah buku dan jurnal ilmiah. Jenis penelitian ini bersifat deskriptif kualitatif. Teknik pengumpulan data yang digunakan dalam penelitian ini adalah teknik baca dan teknik catat. Teknik analisis data menggunakan pendekatan struktural atau objektif. Hasil penelitian ini menunjukkan bahwa peneliti menemukan majas dominan yang terdapat dalam Kumpulan Puisi Karya Mahasiswa FKIP Bahasa dan Sastra Indonesia yaitu majas personifikasi. Wujud gaya bahasa yang terdapat dalam kumpulan tersebut berupa frasa maupun kalimat. Jumlah frasa yang terdapat dalam kumpulan puisi tersebut sebanyak 2 dan terdapat 44 kalimat dalam kumpulan puisi Mahasiswa FKIP Bahasa dan Sastra Indonesia.
\end{abstract}

Kata Kunci: gaya bahasa, personifikasi, puisi.

\begin{abstract}
This study aims to describe the style of language in a collection of poems by students of FKIP Bahasa and Literature University of Balikpapan. The colection of poems by the FKIP student language and bahasa literature works was written by 26 students as many was 52 poems. The primary data source in this study ia a collection of poems by FKIP students of Bahasa and Literature in a number of 60 pages. Secondary data sources in this study are scientific books and journals. This type of research is qualitative descriptive. Data collection techiniques used in this study are reading techniques and note-taaking techniques. Data analysis techniques use a structural or objective approach. The results of this study indicate that the researcher fiund the dominant board found in the Collection of Poetry by Bahasa and Literatur FKIP Students namely majas personification. The form pf language style contained in the collection is in the form of phrases and sentences. The number of phrases contained in the poem collection is 2 and there are 44 sentences in the poetry collection of FKIP Student Bahasa and Literature.
\end{abstract}

Keywords: language style, personification, poetry. 


\section{PENDAHULUAN}

Sastra merupakan wujud gagasan seseorang melalui pandangan terhadap lingkungan sosial yang berada di sekelilingnya dengan menggunakan bahasa yang indah. Sastra hadir sebagai hasil perenungan terhadap fenomen yang ada. Sastra sebagai karya fiksi memiliki pendalaman yang lebih mendalam, bukan sekadar hanya cerita khayal atau angan dari pengarang saja, melainkan wujud dari kreatifitas pengarang dalam menggali dan mengelola gagasan yang ada dalam pikirannya.

Hudson (Munir, 2013:1) menyatakan bahwa sastra merupakan pengungkapan baku dari peristiwa yang telah disaksikan orang dalam kehidupan, yang telah direnungkan, dan dirasakan orang dalam kehidupan yang menarik minat secara langsung dan kuat dari seorang pengarang atau penyair. Sastra hadir sebagai hasil perenungan pengarang terhadap fenomena yang ada.

Dapat disimpulkan bahwa sastra adalah suatu gaya yang dapat diungkapkan melalui ekspresi-ekspresi tersebut menjelaskan secara tidak langsung bisa melalui lisan maupun tulisan. Sastra juga dapat timbul melalui imajinasi yang tinggi sehingga dapat menghasilkan suatu karya yang baik dengan sesuatu hal yang dapat menarik pembaca atau penikmat sastra secara nyata.

Puisi merupakan salah satu genre sastra yang menarik untuk dicermati di samping prosa dan drama. Puisi menggunakan bahasa sebagai medianya. Melalui puisi, pengarang bebas mengungkapkan perasaan dan imajinasinya untuk dituangkan dalam sebuah karya yang bernilai estetis. Sebagai salah satu genre sastra yang menggunakan bahasa bermakna konotasi, di dalam puisi tentu banyak ditemukan bahasa bermajas yang berguna untuk menambah nilai estetika karya tersebut. Menurut Pradopo (2007:7), puisi dapat mengekspresikan pemikiran yang membangkitkan perasaan, yang merangsang imajinasi panca indera dalam susunan yang berirama. Puisi juga merupakan rekaman dan interpretasi pengalaman manusia yang penting kemudian diubah dalam wujud yang paling berkesan.

Wordworth menjelaskan mengenai definisi puisi yakni suatu pernyataan perasaan yang imajinatif, yaitu perasaan yang direkakan atau diangankan. Adapun pembaca ataupun pendengar mengemukakan bahwa puisi lebih merupakan pernyataan yang bercampur-campur (Pradopo, 2014:6). Dunton (Pradopo, 2014:6) berpendapat bahwa 
sebenarnya puisi merupakan pemikiran manusia secara konkret dan artistik dalam emosional serta berirama.

Berdasarkan pendapat para ahli tersebut, disimpulkan bahwa puisi adalah suatu karya lisan maupun tulisan yang berasal dari pemikiran seseorang untuk menghasilkan sebuah kata-kata yang bermacam-macam dan dapat pula menyesuaikan bunyi dari kata-kata tersebut yang sesuai untuk pembacanya.

Majas atau gaya bahasa adalah susunan perkataan yang terjadi karena perasaan yang timbul atau hidup dalam hati penulis yang menimbulkan suatu perasaan tertentu dalam hati pembaca.

Ratna (Santoso, 2016: 6) mengungkapkan gaya bahasa (figure of speech) adalah pilihan kata tertentu yang sesuai dengan maksud pengarang atau pembicara dalam rangka memperoleh aspek keindahan.

Pendapat lain dikemukakan oleh Kosasih (Santoso, 2016: 7), majas adalah bahasa kias, bahasa yang dipergunakan untuk menciptakan efek tertentu. Majas merupakan bentuk retoris yang keguanaannya antara lain untuk menimbulkan kesan imajinatif bagi penyimak atau pembacanya.

Majas atau sering dianggap sebagai anonim dari gaya bahasa, namun sebenarnya majas termasuk dalam gaya bahasa. Majas menjadi bagian dari gaya bahasa yang digunakan untuk mengungkapkan perasaan baik secara lisan maupun tulisan dan dapat menimbulkan reaksi oleh para pendengar atau pembacanya yang berupa tanggapan. Dengan majas, memungkinkan pembaca dapat menilai pribadi, watak, dan kemampuan seseorang yang menggunakan bahasa itu. Semakin baik majas atau gaya bahasanya, semakin baik pula penilaian orang terhadapnya, dan sebaliknya.

Majas, kiasan, figure of speech adalah bahasa kias, bahasa indah yang digunakan untuk meninggikan serta meningkatkan efek dengan jalan memperkenalkan serta memperbandingkan suatu benda atau hal tertentu dengan benda atau hal lain yang lebih umum. Pendek kata, penggunaan majas tertentu dapat mengubah serta menimbulkan nilai rasa atau konotasi tertentu (Tarigan, 2009:112).

Jadi, majas atau gaya bahasa digunakan untuk membantu pembaca dalam memahami isi dan pesan-pesan dalam karyanya juga dapat dipakai untuk meningkatkan kualitas karya sastra itu sendiri. Dari beberapa pendapat yang dipaparkan para ahli sebelumnya, dapat disimpulkan bahwa gaya bahasa adalah salah 
satu bentuk ekspresi khusus yang ada dalam jiwa seseorang secara tidak langsung dapat diungkapkan, karena gaya bahasa tersebut dapat membuat tertarik apa arti dari sebuah kata-kata yang mengandung gaya bahasa tersebut. Jenis majas sendiri secara umum terdiri atas empat yaitu majas perbandingan, majas perumpamaan, majas pertentangan, dan majas sindiran.

Dale menyatakan bahwa personifikasi sebagai salah satu jenis majas berasal dari bahasa latin persona yang berarti orang, pelaku, aktor, atau topeng dalam drama. Oleh karena itu, apabila menggunakan gaya bahasa personifikasi, dapat memberikan ciri-ciri kualitas, yaitu kualitas pribadi orang kepada benda-benda yang tidak bernyawa ataupun kepada gagasan-gagasan (Tarigan, 2009:17).

Kumpulan Puisi Karya Mahasiswa FKIP Bahasa dan Sastra Indonesia Semester V Universitas Balikpapan Tahun 2018 terdiri atas 26 penulis yang menerbitkan 2 karya per-mahasiswa untuk dijadikan antalogi puisi. Tujuan peneliti memilih gaya bahasa personifikasi dalam kumpulan puisi karya mahasiswa FKIP Bahasa dan Sastra Indonesia Universitas Balikpapan karena gaya penggunaannya cukup sulit dipahami maka dari itu peneliti tertarik untuk mencari bentuk gaya bahasa puisi personifikasi tersebut dalam kumpulan puisi mahasiswa FKIP Bahasa dan Sastra Indonesia Universitas Balikpapan.

Dalam penelitian yang berjudul Analisis Majas Personifikasi dalam Kumpulan Puisi Karya Mahasiswa FKIP Bahasa dan Sastra Indonesia Semester V Universitas Balikpapan Tahun 2018. Bahwa kumpulan puisi tersebut banyak menggunakan gaya bahasa yang beragam. Namun pada penelitian ini hanya lebih difokuskan pada penggunaan gaya bahasa personifikasi saja, agar penelitian menjadi lebih fokus dan terarah.

\section{METODE PENELITIAN}

Penelitian ini menggunakan jenis penelitian deskriptif kualitatif. Metode penelitian deskriptif digunakan dalam penelitian ini untuk mendeskripsikan data yang akan dianalisis berupa majas dalam sebuah kumpulan puisi. Sedangkan kualitatif merupakan kajian atau penelitian yang berusaha mengamati dan menafsirkan sesuatu yang menjadi fokus penelitian, dengan tujuan untuk memperoleh pemahaman terhadap unsur yang dianalisis dalam suatu karya dalam hal ini, majas. Sumber data 
dalam penelitian ini terbagi atas sumber data primer yakni kumpulan puisi karya Mahasiswa FKIP Bahasa dan Sastra Indonesia Universitas Balikpapan cetakan pertama di tahun 2018, terdiri atas 60 halaman. Dan sumber data sekunder yang berupa jurnal ilmiah, buku referensi, dan sumber penelitian yang relevan.

Instrumen yang digunakan dalam penelitian ini ialah human instrument, berfungsi untuk menetapkan fokus penelitian, memilih informan sebagai sumber data, melakukan pengumpulan data, memilih kualitas data, analisis data, menafsirkan data dan membuat kesimpulan atas temuannya. Kemudian menggunakan penyajian data teknik lanjutan yaitu teknik baca dengan membaca secara berulang dan teknik catat dengan mencatat data-data tentang majas yang terdapat dalam kumpulan puisi Karya Mahasiswa FKIP Bahasa dan Sastra Indonesia.

Analisis data dalam penelitian ini menggunakan pendekatan sturktural atau objektif. Pendekatan struktural yang meliputi identifikasi data, klasifikasi data, deskripsi data, dan interpretasi data.

\section{PEMBAHASAN}

Peneliti menjabarkan gaya bahasa personifikasi yang didapatkan setelah melakukan penelitian. Telah didapati bentuk penggunaan gaya bahasa personifikasi sebanyak 2 frasa dan 44 kalimat. Di antaranya adalah sebagai berikut:

\section{Data 1}

Jika tetes air mata dapat kuperlihatkan

Entah berapa sumur telah terpenuhi

Jika duka dapat kuperlihatkan

Entah berapa dekapan yang kuingini

\section{Hanya bisa bersembunyi terkurung dalam sunyi} $(001 / \mathrm{P} / \mathrm{PU})$

Puisi di atas menceritakan tentang sebuah pengabdian tentang menunggunya seseorang yaitu yang berprofesi sebagai tentara. Begitu besar luapan rindu yang ia rasakan namun ia tak tega memperlihatkan sedihnya kepada seseorang yang dimaksud. Sehingga ia hanya bisa bersembunyi terkurung dalam sunyi.

Dalam penggalan puisi yang berjudul Pengabdianmu Untuknya, pada bait kedua baris kelima didapati gaya bahasa personifikasi. Gaya bahasa personifikasi merupakan gaya bahasa yang membuat benda mati seolah-olah hidup. Terdapat 
kalimat, bahwa sunyi dianggap sebagai benda yang dapat menutupi dan mampu membuat seseorang bersembunyi dan terkurung, hal tersebut membuatnya seolaholah hidup.

\author{
Data 2 \\ Saat lelakiku harus berjiwa kuat \\ Bukankah pendampingnya harus bermental baja \\ Saat ibunya merelakannya bermandikan peluru \\ Bukankah aku juga harus merelakannya bersetubuh dengan negara \\ Menjadi istri kedua dengan hormat sikap sempurna \\ (002/P/PU dan 003/P/PU)
}

Masih dengan judul yang sama, puisi di atas menceritakan pengorbanan seorang tentara yang mati-matian harus rela mengabdi untuk negara. Dapat dilihat pada kalimat bukankah aku juga harus merelakannya bersetubuh dengan negara, bagaimanapun keadaannya. Bahkan dengan risiko mati pun harus siap ia hadapi. Untuk menjadi istrinya pun, seolah diduakan oleh sosok Dia, dalam puisi tersebut.

Dalam penggalan puisi yang berjudul Pengabdianmu Untuknya, pada bait ketiga baris keempat ditemukan gaya bahasa personifikasi. Karena gaya bahasa personifikasi adalah gaya bahasa yang membuat benda mati seolah-olah hidup layaknya manusia. Pada kalimat, bukankah aku juga harus merelakannya bersetubuh dengan negarabahwa kata bersetubuh menerangkan benda peluru seolah hidup dan mampu melakukan hubungan tersebut.

\title{
Data 3 sampai 5 \\ Untukmu si kepala batu Inginku memaki
}

Namun selimut loreng hijau itu menamparku keras

Baret biru itu memaksaku menelan air mata

Baret biru itu membungkamku tanpa perlawanan (004/P/US, 005/P/US, 006/P/US)

Puisi di atas menceritakan tentang sosok kepala batu, yang dimaksud adalah seorang tentara yang meninggalkan kekasihnya, walaupun kekasihnya tak dapat mengelak kepergiannya. Namun, ia mau tak mau harus menerima kondisi yang terjadi. Bahwa lelakinya mengabdi untuk negeri adalah suatu kebaikan yang tak dapat dipungkiri. Hal itulah yang membuat kekasihnya tak berdaya, hanya bisa menerima keadaan yang sebenarnya. 
Dalam penggalan puisi yang berjudul Untaian Sendu, pada bait kedua baris ketiga terdapat kalimat, namun selimut loreng hijau itu menamparku keras yang termasuk dalam majas personifikasi. Karena benda selimut loreng hijau yang dimaksud menjadi seolah hidup dengan menampar sosok Aku.

Selain itu pada bait keempat, terdapat kalimat baret biru itu memaksaku menelan air mata yang juga termasuk dalam majas personifikasi. Karena baret biru merupakan warna yang melekat dalam baju tentara namun menjadi seolah hidup dengan kondisi memaksa sosok Aku menelan air matanya. Dan terakhir, pada baris kelima terdapat kalimat baret biru itu membungkamku tanpa perlawana. Bahwa baret biru merupakan warna yang melekat dalam baju tentara, namun menjadi seolah hidup dengan kalimat membungkam yang berarti melakukan pergerakan terhadap sosok Aku.

\section{Data 7}

Untukmu si kepala batu

Kini apalah arti merindu dan dirindu

Di saat tugas dan perintah adalah orang tuamu

Senjata dan amunisi menjadi istri pertamamu

(007/P/US)

Puisi di atas masih menggambarkan tentang sosok Aku yang diceritakan oleh kekasihnya. Saking sibuknya menjadi pengabdi negara yang siap siaga untuk melakukan peperangan, lelakinya sangat dekat dengan senjata dan amunisi hingga diibaratkan menjadi sosok istri pertamanya. Sebab kekasihnya mulai dikesampingkan.

Dalam penggalan puisi yang berjudul Untaian Sendu, pada bait ketiga baris keempat terdapat majas personifikasi. Karena majas personifikasi membuat benda mati menjadi seolah-olah hidup. Senjata dan amunisi adalah sebuah benda yang digunakan untuk berperang, jelaslah benda tak dapat melakukan perkawinan. Dan dianggap menjadi seolah hidup dengan keberadaan kata istri, maksudnya sosok Aku ditinggal oleh sesorang yang dimaksud karena bertugas menjadi tentara.

\section{Data 8}

Masih kusaksikan langit kala itu

Melukis rona jingga kemerah-merahan dari ujung kaki langit

Semenit, lima menit tak lama

$(008 / \mathrm{P} / \mathrm{BL})$ 
Puisi di atas menceritakan seseorang yang kesepian yang gemar memperhatikan fenomena langit untuk menghibur dirinya.

Dalam penggalan puisi yang berjudul Bercengkrama Langit, pada bait kedua baris pertama menggunakan gaya bahasa personifikasi. Gaya bahasa personifikasi adalah gaya bahasa yang membuat benda mati seolah-olah hidup layaknya manusia. Bahwa Langit dianggap dapat melukis hal inilah yang menjadikannya hidup.

\section{Data 9 dan 10}

Masih kusaksikan langit kala itu

Walau pekat namun didampingi kerlap

Disertai purnama yang kesepian

Menemaniku istirahat di pembaringan

(009/P/BL, 010/P/BL)

Berkaitan dengan bait sebelumnya, penggalan puisi pada bait di atas menggambarkan sosok yang kesepian namun keberadaan benda-benda langit membuat hari-harinya dihiasi dan berwarna.

Dalam pengalan puisi yang berjudul Bercengkrama Langit, pada bait ketiga baris kedua dan ketiga terdapat gaya bahasa personifikasi. Gaya bahasa personfikasi merupakan gaya bahasa yang membuat benda mati seolah-olah hidup layaknya manusia. Pada kalimat, walau pelat namun didampingi kerlap dijelaskan bahwa langit dianggap berdampingan, padahal yang pantas mendampingi adalah sosok yang hidup yang mampu menjaga dan merawatnya.

Selain itu pada baris ketiga, juga menggunakan majas personifikasi di mana dapat dilihat pada kalimat disertai purnama yang kesepian. Purnama yang dimaksud adalah bulan, dianggap seolah hidup karena ia merasa kesepian padahal purnama bukan makhluk hidup yang memiliki perasaan.

\section{Data 11}

Aku adalah saksi langit

Yang sedari tadi asyik bercengkrama

Dengan fajar, senja dan malam

Terjebak... terperangkap

(011/P/BL) 
Puisi di atas menceritakan sosok yang kesepian dan asyik bercengkrama dengan fajar, senja, dan malam. Ia sangat menikmati keberadaan waktu dan perubahannya. Sebab baginya semua itu berharga dan mampu menemaninya.

Dalam penggalan puisi yang berjudul Bercengkerama Langit, pada bait keempat baris kedua dan ketiga menggunakan gaya bahasa personifikasi. Gaya bahasa personifikasi adalah gaya bahasa yang membuat benda mati seolah-olah hidup. Digambarkan pada kalimat, yang sedari tadi asyik bercengkerama dengan fajar, senja dan malam. Dan yang membuatnya seolah hidup adalah sosok aku bercengkrama dengan fajar, senja, dan malam padahal kesemua itu tidak dapat diajak berbicara layaknya manusia.

\title{
Data 12 \\ Mengingat kembali dirimu \\ Keterasingan dan sunyi menyapa \\ Menulisi air mata, di antara kata-kata liar buruanku \\ Mengaliri duka cita tak pernah tamat kubaca \\ (012/P/SR)
}

Puisi di atas menceritakan sosok yang tiba-tiba saja mengingat seseorang dan merindukannya, namun ia tak dapat melakukan apapun dan hanya bisa menangisi sosok tersebut.

Penggalan puisi yang berjudul Senyapan Rindu pada bait pertama baris kedua menggunakan gaya bahasa personifikasi. Pada kalimat tersebut, keterasingan dan sunyi dianggap seolah hidup karena mereka seolah menyapa, padahal yang bisa menyapa hanya makhluk yang dilengkapi indera.

\author{
Data 13 \\ Tiba-tiba rinduku padamu \\ Menjelma sebuah menara menjulang \\ Mengajari udara berterbangan \\ Dengan kesabaran \\ (013/P/SR)
}

Puisi di atas menceritakan sebuah kerinduan yang hakiki. Di mana kerinduan yang datang ia terima dengan kelapangan, ia tak berusaha mengelaknya namun menerimanya walaupun rindu tersebut bergejolak. 
Penggalan puisi yang berjudul Senyapan Rindu pada bait kedua baris ketiga menggunakan gaya bahasa personifikasi. Gaya bahasa personifikasi adalah gaya bahasa yang membuat benda mati seolah-olah hidup layaknya manusia. Sebab udara adalah benda mati yang tak bisa diajak untuk belajar seperti manusia. Oleh karena itu, dianggap seolah hidup.

\section{Data 14}

Dan aku di sini, di puncak kerinduan ini

Beribu tahun memunguti kesepian tak terperi

Dalam ketidakberdayaan, di ruang kefanaanku

(014/P/SR)

Puisi di atas menceritakan kerinduan seseorang yang tak berdaya mengutarakan rasa rindunya kepada sosok yang dimaksud selama bertahun-tahun sehingga ia hanya bisa merindukan dalam kesenyapan.

Penggalan puisi yang berjudul Senyapan Rindu pada bait keempat baris kedua menggunakan gaya bahasa personifikasi. Gaya bahasa personifikasi adalah gaya bahasa yang membuat benda mati seolah-olah hidup.Sepi menjadi seolah hidup karena dipungut atau dijadikan seorang teman bagi sosok Aku.

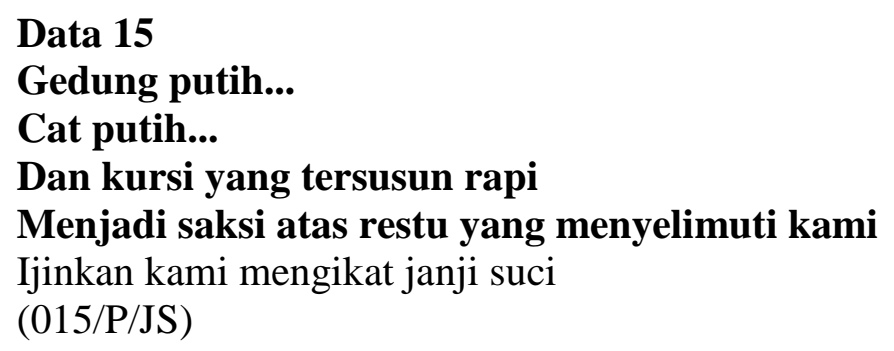

Penggalan puisi di atas menceritakan seseorang yang menginginkan untuk segera dinikahi. Dan mengibaratkan gedung putih, cat putih, dan kursi menjadi saksi buta mereka.

Pada penggalan puisi yang berjudul Janji Suci terdapat gaya bahasa personifikasi bait ketiga baris pertama hingga keempat. Gaya bahasa personifikasi adalah gaya bahasa yang membuat benda mati menjadi seolah-olah hidup. Karena pada kalimat gedung putih, cat putih, dan kursi adalah benda mati yang dianggap seolah hidup dengan menjadi restu atau menyaksikan sesuatu. 


\section{Data 16}

Sayang, jika kau besar nanti

Ingatlah kita pernah menari dalam dekap

Saling membasuh luka dan pilu

\section{Kita sisir satu persatu takut}

(016/P/A)

Puisi di atas menceritakan kasih sayang seorang kakak kepada adiknya, ia berusaha menguatkan adiknya untuk tetap berani menghadapi segala rintang dalam hidup. Sebab masalah akan semakin berat jika seseorang telah dewasa.

Pada penggalan puisi yang berjudul Adikku, pada bait pertama baris keempat didapati penggunaan gaya bahasa personifikasi. Gaya bahasa personifikasi adalah gaya bahasa yang membuat benda mati seolah-olah hidup. Dapat dilihat pada kalimat kita sisir satu per satu rasa takut. Padahal takut adalah sebuah rasa yang tak dapat disentuh, namun seloah menjadi benda mati yang hidup karena disisir.

\section{Data 17}

Dering telepon memecah malam

Pergantian hari di detik-detik awal

Menghadirkan kamu di sisi

Mengucap langsung kata-kata itu

(017/P/SUT)

Puisi di atas menggambarkan perasaan seseorang terhadap kasihnya pada hari ulang tahunnya. Namun, sang kekasih tak dapat bertemu langsung dengannya sebab keberadaannya amat jauh sehingga hanya dapat mengucapkannya via telepon.

Pada penggalan puisi yang berjudul Selamat Ulang Tahun, pada bait pertama baris pertama menggunakan gaya bahasa personifikasi. Dapat dilihat pada frasa dering telepon yang merupakan benda mati yang tak dapat melakukan pergerakan untuk memecah malam. Sehingga dianggap seolah hidup.

\section{Data 18}

Tiada kado terindah selain kepulanganmu

Bingkisan dengan rindu yang kau tampung

Bau pesawat dengan mata lelah

Iklim berbeda gugur semi panas hujan

Kita membungkus dengan waktu

(018/P/SUT) 
Pada puisi di atas menggambarkan harapan hadiah ulang tahun yaitu kepulangan kekasihnya. Namun tak dapat diwujudkan karena sang kekasih berada nan jauh dari dirinya.

Pada penggalan puisi Selamat Ulang Tahun, pada bait kedua baris kelima terdapat gaya bahasa personifikasi. Gaya bahasa personifikasi adalah gaya bahasa yang menjadikan benda mati seolah-olah hidup. Karena waktu adalah benda yang tak dapat disentuh, oleh karena itu dianggap seolah hidup dengan kata dibungkus.

\section{Data 019 \\ Setelah telepon mati \\ Maaf rasa senangku menjadi sendu \\ Usiaku bertambah \\ Namun rinduku tumbuh lebih cepat (019/P/SUT)}

Puisi di atas masih berhubungan dengan bait sebelumnya, yakni mengenai ungkapan kerinduan sepasang kekasih di hari ulang tahunnya. Pada penggalan puisi Selamat Ulang Tahun, pada bait kelima baris keempat terdapat gaya bahasa personifikasi. Gaya bahasa personifikasi adalah gaya bahasa yang membuat benda mati seolah-olah hidup. Dilihat dari kata rindu tak dapat tumbuh layaknya makhluk hidup, oleh karena itu dianggap sebagai seolah hidup.

\section{Data 020 dan 021}

Membawa bulan sabit di matanya

Membawa api unggun di jemarinya

Pelangi bunga krisan selalu ada padanya

(020/P/NO, 021/P/NO)

Puisi di atas menceritakan tentang rasa suka seseorang yang disimpannya secara diam-diam. Penulis merasa sosok tersebut merupakan sosok yang indah bahkan tatapannya, jemarinya, dan dirinya dinggambarkan dengan tajamnya bulan sabit, hangatnya api unggun, dan indahnya bunga krisan.

Pada penggalan puisi berjudul Nerium Oleander, pada bait keempat baris kedua dan ketiga menggunakan gaya bahasa personifikasi. Gaya bahasa personifikasi adalah gaya bahasa yang membuat benda mati seolah-olah hidup layaknya manusia. Pertama, bulan sabit dianggap seolah hidup karena dapat dibawa ke mata, padahal itu 
merupakan hal yang mustahil. Kedua, api unggun dianggap seolah hidup karena dapat dibawa padahal api unggun benda yang panas dan seolah hidup dengan dibawa.

\section{Data 22}

\section{Tangis itu menghampiriku lagi}

Meski begitu

Tak ada satupun sentuhan telapak tangan

Menghapus air mata yang mengalir membasahi pipiku (022/P/SB)

Puisi di atas menceritakan tentang kesedihan seseorang sebab tak sanggup menahan beban derita hidupnya. Karena ia terlahir sebagai si bungsu yang menanggung beban keluaganya dalam merawat ibunya tanpa dipedulikan oleh saudara-sudara lainnya.

Pada penggalan puisi berjudul Si Bungsu, pada bait pertama baris pertama menggunakan gaya bahasa personifikasi karena gaya bahasa personifikasi mampu membuat benda mati seolah-olah hidup layaknya manusia. Dapat dilihat bahwa tangis dianggap seolah hidup karena kata menghampiri, sebab yang dapat menghampiri harusnya benda hidup yang dapat berjalan.

\section{Data 23 \\ Bekerja dengan hati \\ Bersyukur tiap waktu \\ Beramal dalam sehari \\ Yang pasti bersujudlah di hadapan Tuhanmu \\ (023/P/KD)}

Puisi di atas menceritakan seseorang yang memberikan pencerahan kepada pembaca bahwa perlunya manusia melakukan kebaikan. Dan yang terpenting adalah manusia yang beribadah kepada Tuhan-Nya.

Penggalan puisi yang berjudul Kenali Dirimu menggunakan gaya bahasa personifikasi. Gaya bahasa personifikasi adalah gaya bahasa yang membuat benda mati seolah-olah hidup. Pada bait ketiga baris pertama dapat dilihat bahwa hati adalah benda mati yang tak dapat melakukan pekerjaan, maka ia dianggap seolah hidup.

\section{Data 24}

Walau badai berusaha menghalangi langkahmu

Kau tak pernah pantang menyerah 
Segalanya kau usahakan

$(024 / \mathrm{P} / \mathrm{I})$

Puisi di atas menceritakan perjuangan seorang ibu, bahwa tak ada yang dapat menyurutkan semangat dan perjuannya. Sekalipun badai menerpa dirinya.

Pada penggalan puisi berjudul $I b u$, pada bait kedua baris pertama menggunakan gaya bahasa personifikasi. Gaya bahasa personifikasi adalah gaya bahasa yang membuat benda mati seolah-olah hidup layaknya manusia. Dapat dilihat bahwa badai dianggap seolah hidup karena ia berusaha menghalangi, padahal badai tak mampu menghalangi pergerakan seseorang.

\section{Data 25 \\ Senyummu.. \\ Tawamu... \\ Lirikanmu... \\ Semua menikam tepat di jantungku \\ (025/P/B)}

Puisi di atas menggambarkan sebuah perasaan yang dirasakan seorang yang sedang jatuh cinta. Bahwa segala yang dilakukannya membuat seorang tersebut jatuh hati atau deg-degan.

Pada penggalan puisi berjudul Bingung, pada bait kelima baris keempat menggunakan gaya bahasa personifikasi karena gaya bahasa personifikasi adalah gaya bahasa yang membuat benda mati seolah-olah hidup. Pada kalimat lirikanmu, menikam tepat dijantungku menyatakan bahwa lirikan tak mampu memukul seseorang apalagi menikam, hal itulah yang membuat kata lirikan menjadi seolah hidup.

\section{Data 26 \\ Kau temani aku layaknya senja \\ Datang sore meninggalkan siang \\ Dan tidak bisa hadir pada petang \\ Tak bisakah kau menetap \\ (026/P/PAJS)}

Puisi tersebut menceritakan tentang seseorang yang dilukiskan dengan senja. Baginya, senja selalu membawa kenangan pada sosok yang ia cintai, namun tak 
pernah dapat ia miliki. Sebab ia selalu berlalu datang dan pergi. Tak pernah menetap di hati.

Pada penggalan puisi berjudul Percaya Akan Janji Semu, pada bait pertama baris pertama menggunakan gaya bahasa personifikasi, karena gaya bahasa tersebut dapat membuat benda mati seolah hidup layaknya manusia. Senja adalah benda mati yang hadirnya tak dapat menemani maupun menghibur seseorang.

\section{Data 27}

Aku terlalu percaya pada manis

Sehingga mengacuhkan rasa pahit

Aku terlalu percaya pada bahagia

Sehingga mengesampingkan duka lara

(027/P/PAJS)

Puisi di atas menggambarkan perasaan seseorang yang selalu dikecewakan berkali-kali akan janji manis lelaki. Namun demikian, ia tak pernah jera, selalu menerima janji manis yang diucapkan seorang lelaki kepadanya.

Pada penggalan puisi yang berjudul Percaya Akan Janji Semu, pada bait kedua baris kedua menggunakan gaya bahasa personifikasi. Gaya bahasa personifikasi adalah gaya bahasa yang membuat benda mati seolah-olah hidup layaknya manusia. Frasa rasa pahit dianggap seolah hidup karena kata mengacuhkan, yang dianggap mampu melakukan hal demikian padahal tidak.

\section{Data 28}

Ketika sang fajar mulai mengintip di balik awan

Ketika embun menghiasi dedaunan

Suara rintik hujan tetap ada

Walaupun sudah sedikit reda

(028/P/KM)

Puisi di atas menggambarkan suasana di pagi hari setelah hujan. Penulis mengkiaskan pagi dengan kata fajar yang mulai naik dengan kata mengintip. Suasana tersebut digambarkan, karena bagi penulis suasana tersebut merupakan suasana yang amat sejuk dan meneduhkan.

Pada penggalan puisi yang berjudul Kisah Malamku, pada bait ketiga baris kedua didapati penggunaan gaya bahasa personifikasi. Gaya bahasa personifikasi adalah gaya bahasa yang membuat benda mati seolah-olah hidup. Bahwa fajar merupakan 
benda mati yang tak dapat mengintip, yang dapat mengintip hanyalah sosok yang memiliki mata. Hal itulah yang membuatnya seolah hidup.

\section{Data 29 \\ 029/P/KM \\ Hari kini mulai terang \\ Kucoba buka kelopak mata}

Selimut malam masih setia menemaniku

Hangatnya sisa-sisa malam

Puisi di atas menceritakan tentang perasaan seseorang tatkala di malam hari dan bangun di pagi hari. Ia merasakan kenyamanan karena bangun dari tidur yang nyenyak dan mimpi indah yang ia alami.

Pada penggalan puisi yang berjudul Kisah Malamku, pada bait keempat baris ketiga menggunakan gaya bahasa personifikasi. Gaya bahasa personifikasi adalah gaya bahasa yang membuat benda mati seolah-olah hidup layaknya manusia. Dapat dilihat dari kata selimut yang merupakan benda mati yang tak memiliki perasaan sehingga ia tak bisa berlaku setia seperti manusia. Oleh karena itu, ia dianggap sebagai benda mati.

\section{Data 30 \\ Lelah daku dalam sepiku \\ Lelah daku dalam kesendirian batinku \\ Cahaya itu telah pergi dari kehidupanku \\ Kehidupanku saat bersama dirimu \\ (030/P/AYH)}

Puisi di atas menggambarkan tentang kepergian seseorang. Seseorang itu diibaratkan sebuah cahaya, baginya cahanya adalah harapan hidupnya dalam menjalani hari-hari. Dalam bait tersebut, penulis mengenang sosok tersebut dan seketika lelah dengan kesendirian yang ia alami

Pada penggalan puisi yang berjudul Asaku Yang Hilang, pada bait pertama baris ketiga menggunakan gaya bahasa personifikasi. Gaya bahasa personifikasi adalah gaya bahasa yang menjadikan benda mati seolah-olah hidup. Pada kalimat cahaya itu t’lah pergi dari kehidupanku menjadi seolah hidup karena kata pergi membuat cahaya seolah dapat berjalan seperti seseorang yang memiliki kaki layaknya makhluk hidup. 


\section{Data 31}

Demi aku...

Kau rela mati disengat matahari

\section{Hujan pun tak dapat membatasimu}

Betapa mulianya hatimu

(031/P/RSA)

Puisi di atas menceritakan sosok Sang Ayah dengan segala pengorbanannya terhadap anak-anaknya. Ayah tak pernah peduli dengan apa yang akan terjadi pada dirinya. Yang terpenting adalah anaknya dapat bahagia sebab ia berusaha memenuhi segala keinginan anaknya.

Pada penggalan puisi yang berjudul Rahasia Sang Ayah, pada bait ketiga baris kedua didapati penggunaan gaya bahasa personifikasi. Karena gaya bahasa personifikasi membuat benda mati seolah-olah hidup layaknya manusia. Terbukti pada kata membatasi membuat hujan seolah hidup dan dapat melakukan sesuatu atau membuat batas bagi seseorang, yang dimaksud adalah kamu.

\section{Data 32}

\section{Kini tanahmu tak lagi subur}

Lingkungan tak lagi bersahabat

Kenapa heran?

Heran dengan semua yang terjadi?

(032/P/PA)

Puisi di atas menceritakan tentang kondisi alam yang tak lagi asri. Ditandai dengan tanah yang tak lagi subur, lingkungan tak bersahabat karena begitu banyaknya penebangan liar hingga menyebabakan polusi udara. Penulis menganggap bahwa manusia terkadang kerapkali mengeluh dengan keadaan yang terjadi, namun ternyata tersangka perusak alam sendiri adalah manusia itu yang tak bertanggung jawab. Maka tak perlu heran dengan kondisi yang terjadi.

Pada penggalan puisi yang berjudul Perusak Alam, pada bait pertama baris kedua menggunakan gaya bahasa personifikasi. Gaya bahasa personifikasi adalah gaya bahasa yang membuat benda mati seolah-olah hidup. Terdapat pada kata kingkungan menjadi seolah hidup karena dapat bersahabat layaknya manusia.

\section{Data 33}

\section{Hai hujanku}


Apa kabar kamu?

Aku yakin kamu baik-baik saja dan bahagia

Semenjak kejadian itu aku meneteskan air mata

$(033 / \mathrm{P} / \mathrm{H})$

Puisi di atas menggambarkan kecemasan seseorang akan kekasihnya. Ia trauma dengan tragedi di kala hujan, yang pada saat turun hujan ia selalu mengingat kejadian yang tidak mengenakkan terjadi kepada kekasihnya. Sehingga saat hujan turun, ia selalu menyapa hujan, yang dianggapnya adalah kekasihnya.

Pada penggalan puisi yang berjudul Hujanku, pada bait pertama baris pertama menggunakan gaya bahasa personifikasi. Gaya bahasa personifikasi dapat menjadikan benda mati seolah-olah hidup. Dibuktikan dengan kata "Hai” di mana penulis menganggap hujan seolah manusia yang dapat disapa padahal tidak.

\section{Data 34}

Restu...

Ia aku mengharapkan sebuah restu

Untuk restu yang tak pernah memeluk kita

Untuk restu yang tak kunjung pernah kudapat

(034/P/R)

Puisi di atas menceritakan seseorang yang butuh restu dalam hubungannya. Ia sangat butuh kata restu dalam hubungannya karena mereka adalah dua sejoli yang saling mencintai, namun selalu saja restu itu tak pernah ia dapatkan dan tak pernah berpihak padanya.

Pada penggalan puisi yang berjudul Restu, pada bait pertama baris ketiga didapati penggunaan gaya bahasa personifikasi. Gaya bahasa personifikasi adalah gaya bahasa yang membuat benda mati seolah-olah hidup layaknya manusia. Di mana restu dianggap seolah hidup karena dapat memeluk seperti manusia, namun kenyataannya tidak demikian.

\section{Data 35}

Namanya manusia

Suka bermimpi untuk membunuh waktu

Namun, tiada berbuat sesuatu

(035/P/M) 
Puisi di atas menggambarkan kelalaian manusia dalam memanfaatkan waktu yang ada. Manusia selalu menginginkan waktu yang cepat berlalu, namun seiring berputarnya waktu yang kian cepat manusia tak pernah berbuat apa-apa, tanpa perubahan dalam dirinya. Inilah yang membuat manusia mengalami kerugian.

Pada penggalan puisi yang berjudul Manusia, pada bait pertama baris kedua adalah gaya bahasa personifikasi. Karena menjadikan benda mati seolah-olah hidup layaknya manusia. Dapat dibuktikan bahwa waktu adalah benda mati yang dianggap seolah hidup karena dapat dimimpikan.

\section{Data 36 \\ Kenangan masa lalu datang tanpa permisi \\ Kenangan yang telah lama terlupakan \\ Kenangan yang tak diinginkan (036/P/R)}

Puisi tersebut menceritakan tentang kegundahan penulis akan sebuah kenangan. Kenangan baginya selalu datang tanpa permisi dan tak pernah dapat dilupakan. Lebih parahnya kenangan tersebut bukan kenangan yang indah untuk diingat, hingga terkadang penulis kesal apabila tiba-tiba mengingat suatu kenangan.

Pada penggalan puisi berjudul Rindu, pada bait pertama baris pertama menggunakan gaya bahasa personifikasi. Gaya bahasa personifikasi adalah gaya bahasa yang membuat benda mati seolah hidup. Terbukti bahwa,, kenangan adalah kumpulan memori yang terdapat dalam diri manusia, namun kenangan tak mampu berbicara sehingga ia dianggap seolah hidup dengan kata tanpa permisi.

\section{Data 37}

Aku sungguh tidak mengerti

Merindukanmu yang tak pernah kumiliki

Terkurung dalam kenangan yang enggan pergi (037/P/R)

Puisi tersebut menggambarkan perasaan penulis yang tak mengerti akan perasaannya sendiri. Sebab ia merasa perasaan yang ada dalam dirinya sangat mengganggunya, karena ia merasa tak pantas merindukan seseorang yang tak pernah ia miliki. Rasanya seperti sia-sia saja. Dan hal tersebut tak kunjung pergi, selalu saja ada dan tersimpan dalam memori kenangan. 
Pada penggalan puisi yang berjudul Rindu, pada bait ketiga baris ketiga didapati penggunaan gaya bahasa personifikasi. Gaya bahasa personifikasi adalah gaya bahasa yang membuat benda mati seolah-olah hidup. Dilihat bahwa kenangan tidak memiliki kaki yang dapat berjalan pergi, melainkan kenangan hanya bisa dihapus oleh karena itu dianggap menjadi seolah-olah hidup.

Data 38, 39, dan 40

Hujanku seakan tak lagi bersyair

Ada sajak yang tlah hilang dalam semilir angin

Hujanku pergi tanpa permisi

Meninggalkanku sendiri dalam keheningan puisi

(038/P/HM, 039/P/HM, 040/P/HM)

Puisi di atas menggambarkan sosok hujan yang diibaratkan seseorang. Sosok tersebut tak pernah lagi datang kepada dirinya memberikan sepucuk syair yang indah. Bahkan sajak-sajak yang ditulisnya perlahan hilang. Kemudian ia pergi tanpa pamit tanpa mempedulikan perasaannya.

Pada penggalan puisi yang berjudul Hujanku Menghilang, pada bait pertama baris pertama, kedua, dan ketiga menggunakan gaya bahasa personifikasi karena gaya bahasa tersebut dapat membuat benda mati seolah-olah hidup layaknya manusia. Pertama, hujan bukan sosok manusia yang mampu mengekspresikan sesuatu dengan bahasa, ia adalah benda mati dan dianggap seolah hidup karena tak lagi bersyair. Kedua, semilir angin adalah benda mati yang dianggap seolah hidup karena menghilangkan suatu sajak. Ketiga, semilir angin adalah benda mati yang dianggap seolah hidup karena menghilangkan suatu sajak.

\section{Data 41 \\ Kau yang setia melanutunkan rintikan indah kini tlah pergi Hilang bersama penyair yang mungkin takkan kembali \\ Tak ada lagi naungan tuk menari \\ Bersembunyi dalam sajak sepi \\ Bak puisi yang tlah lama usang (041/P/HM)}

Puisi di atas masih berkaitan dengan sebelumnya, bahwa penulis menceritakan seseorang yang hilang tiba-tiba. Dan ia merindukan sajak-sajak yang pernah kekasihnya tulis kala itu. 
Pada penggalan puisi yang berjudul Hujanku Menghilang, pada bait kedua baris keempat menggunakan gaya bahasa personifikasi karena gaya bahasa tersebut dapat menjadikan benda mati seolah-olah hidup layaknya manusia. Hujan bukan makhluk hidup yang dapat berbicara dan mengatakan permisi atau izin sebelum pergi oleh karena itu dianggap seolah hidup.

\section{Data 42 dan 43}

Kala itu, kudapati jingga sedang berjuang menuju senja

Tanpa menghentikan jarum waktu ia melintasi cakrawala

Bersama angin memainkan fantasi jingganya

\section{Sambil tersenyum lirih ia menari-nari di atas senjaku}

(042/P/JDUS, 043/P/JDUS)

Puisi di atas menceritakan suasana indahnya sunset di sore hari. Bahwa ketika sore datang, jingga dikiaskan berjalan menuju senja dengan semilir angin yang redup membuat penulis tersenyum dan merasakan ketenangan sebab keberadaan senja dan sunset.

Pada penggalan puisi yang berjudul Jingga di Ujung Senjaku, pada bait pertama baris pertama dan keempat menggunakan gaya bahasa personifikasi. Pertama, jingga dianggap seolah hidup karena mampu berjuang menuju atau menghampiri senja, padahal jingga tak mempunyai kaki yang dapat berjalan sehingga tak dapat bergerak dan menghampiri. Kedua, senja dianggap seolah hidup karena mampu menari-nari di atasnya.

\section{Data 44}

Aku pun merasa bahwa jingga akan kehilangan senjanya

Tertiup angin, terhempas, dan tertimbun dalam kesenyapan

Tak berdaya hingga membuatnya berada di ujung senja (044/P/JDUS)

Puisi di atas masih sama dengan sebelumnya yakni menceritakan senja dan rona jingga yang ada padanya. Penulis menganggap bahwa ia tidak bertemu dengan senja yang indah apabila tak ada warna jingga yang menghiasinya. Dan warna jingga tersebut tak semburat indah di kaki langit secara menyeluruh, melainkan hanya mewarnai langit separuh saja.

Pada penggalan puisi yang berjudul Jingga di Ujung Senjaku, pada bait keempat baris pertama menggunakan gaya bahasa personifikasi karena gaya bahasa tersebut 
membuat benda mati seolah-olah hidup layaknya manusia. Dapat dilihat bahwa jingga adalah sebuah benda yang tak memiliki perasaan, maka seolah hidup ketika jingga merasa kehilangan.

\section{Data 45 \\ Mengapa ada jarak yang menghentikan jarum waktu \\ Inginku raih peraduan sore kala itu \\ Namun, aku hanya bisa berada di ujung senjaku \\ Andai langit tak datang mencuri sore \\ Pasti sketsa senjaku akan tetap utuh bersama hingga \\ (045/P/JDUS)}

Puisi di atas menceritakan tentang jingga yang berada di ujung senja. Menandakan bahwa keberadaan senja mulai menghilang dan menandakan bahwa sore mulai beranjak malam. Namun, penulis sebagai penikmat senja melukiskan senja dengan begitu berarti, dan ia sangat berharap agar senja tak segera usai.

Pada penggalan puisi yang berjudul Jingga di Ujung Senjaku, pada bait kelima baris keempat didapati penggunaan gaya bahasa personifikasi karena gaya bahasa tersebut dapat menjadikan benda mati seolah-olah hidup layaknya manusia. Bahwa langit merupakan benda yang tak dapat melakukan pergerakan bebas layaknya manusia, maka dianggap seolah hidup dengan kata mencuri.

\section{Data 46}

Ku tatap jendela kamarku

Bermain mata dengan sejuknya embun pagi

Kutentukan pilihan

Mulailah aku beranjak

Dengan secangkir teh panasku

$(046 / \mathrm{P} / \mathrm{K})$

Puisi di atas menceritakan seseorang yang bangun di pagi hari. Ia sangat menikmati datangnya pagi. Mulai dari membuka jendela kamar, dan beranjak untuk menyeduh segelas teh panas. Pagi harinya begitu menenangkan bahkan dengan nakalnya penulis mengibaratkan seseorang tersebut dapat bermain mata dengan embun pagi.

Pada penggalan puisi yang berjudul Penikmat, pada bait pertama baris kedua menggunakan gaya bahasa personifikasi. Gaya bahasa personifikasi adalah gaya bahasa yang membuat benda mati seolah-olah hidup. Dibuktikan dengan adanya 
benda mati yaitu embun pagi yang tak dapat melihat apalagi sampai diajak untuk bermain mata, maka dianggap seolah hidup layaknya manusia.

\section{PENUTUP}

Dari hasil penelitian dan pembahasan yang telah diperoleh dalam bab-bab sebelumya dapat disimpulkan bahwa terdapat 46 gaya bahasa personifikasi. Gaya bahasa personifikasi adalah gaya bahasa yang menjadikan benda mati seolah-olah hidup layaknya manusia.

Berdasarkan kumpulan puisi Mahasiswa FKIP Bahasa dan Sastra Indonesia Semester V yang berjumlah sebanyak 52 puisi yang ditulis oleh 26 mahasiswa. Wujud gaya bahasa yang terdapat dalam kumpulan tersebut berupa frasa maupun kalimat. Jumlah frasa yang terdapat dalam kumpulan puisi tersebut sebanyak 2 dan jumlah kalimat yang terdapat dalam kumpulan puisi tersebut sebanyak 44 .

Dalam kumpulan puisi Mahasiswa FKIP Bahasa dan Sastra Indonesia Semester V gaya bahasa personifikasi yang dominan terdapat pada judul puisi Bercengkrama Langit dan Senyapan Rindu. Di mana terdapat masing-masing 4 gaya bahasa personifikasi yang terdapat dalam puisi tersebut. Hal ini terdapat karena curahan perasaan penulis yang begitu mendalam, puisi Bercengkerama Langit menceritakan tentang sosok yang kesepian namun langit dapat menjadi teman dalam kesehariannya. Sedangkan puisi Senyapan Rindu menceritakan tentang kerinduan yang tak dapat diungkapkan sebab sosok yang dirindukan telah menghilang pergi.

Dengan demikian, gaya bahasa dapat digunakan sebagai penekanan makna dalam puisi. Gaya bahasa sangat berperan pening, karena dapat menjadikan pembaca dapat menikmati keindahannya.

\section{DAFTAR RUJUKAN}

Aprianti, Annika, dkk. 2012. Kategori dan Fungsi Majas dalam Lirik Lagu Album Bintang Lima Dewa 19. Jurnal Penelitian Vol. 1 No. 1. Universitas Negeri Padang.

Kumpulan Puisi Mahasiswa FKIP Bahasa dan Sastra Indonesia. 2018. FKIP Universitas Balikpapan. 
Mujiyati, Sri. 2016. Penggunaan Majas Perbandingan dalam Puisi Karya Siswa Kelas VIII di SMP Negeri 3 Colomadu Tahun Ajaran 2015/2016. Pubikasi Ilmiah. Universitas Muhammadiyah Surakarta.

Munir, Saiful. 2013. Diksi dan Majas dalam Kumpulan Puisi Nyanyian dalam Kelam Karya Sutikno W.S: Kajian Stalitstika. Jurnal Penelitian. Vol.2 PP. 1-10.

Novianti, Hasmi. 2018. Penggunaan Majas dalam Puisi Menggunakan Media Lagu Siswa Kelas VIII SMP Negeri 4 Satu Atap Sungai Liku Kecamatan Ranah Pesisir Kabupaten Pesisir Selatan. Jurnal Penelitian Vol. 4 No. 1 ISSN 25793036. Universitas Nusantara PGRI.

Pradopo, Rachmat Djoko. 2007. Pengkajian Puisi. Yogyakarta: Gadjah Mada University Pers.

Santoso, Sugeng. 2016. Majas dalam Novel Semesta Mendukung Karya Ayu Widya. Jurnal Penelitian Vol. 2 No. 1 E-ISSN 2503-3875. Bastra FKIP UHO.

Sugiyono. 2016. Metode Penelitian Pendidikan Pendekatan Kuantitatif, Kualitatif, dan $R$ \& $D$. Bandung: Alfabeta.

Tarigan, Henry Guntur. 2009. Pengajaran Gaya Bahasa. Bandung: Angkasa 